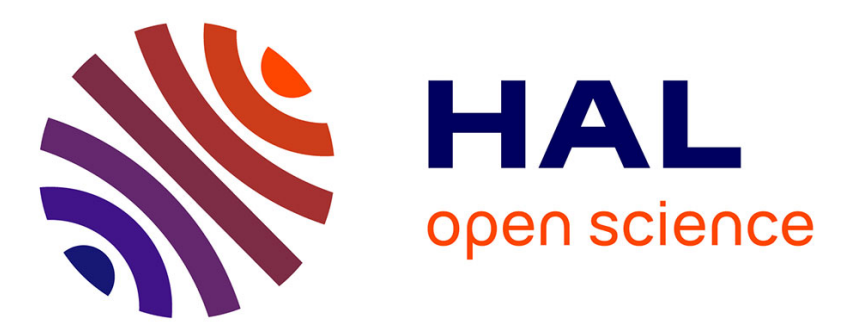

\title{
How the French GM controversy led to the reciprocal emancipation of scientific expertise and policy making
}

Claire Marris, Pierre-Benoît Joly, Stéphanie Ronda, Christophe Bonneuil

\section{To cite this version:}

Claire Marris, Pierre-Benoît Joly, Stéphanie Ronda, Christophe Bonneuil. How the French GM controversy led to the reciprocal emancipation of scientific expertise and policy making. Science and public policy, 2005, vol. 32 ( $\left.{ }^{\circ} 4\right)$, pp.301-308. hal-00175989

\author{
HAL Id: hal-00175989 \\ https://hal.science/hal-00175989
}

Submitted on 2 Oct 2007

HAL is a multi-disciplinary open access archive for the deposit and dissemination of scientific research documents, whether they are published or not. The documents may come from teaching and research institutions in France or abroad, or from public or private research centers.
L'archive ouverte pluridisciplinaire HAL, est destinée au dépôt et à la diffusion de documents scientifiques de niveau recherche, publiés ou non, émanant des établissements d'enseignement et de recherche français ou étrangers, des laboratoires publics ou privés. 


\title{
France
}

\section{How the French GM controversy led to the reciprocal emancipation of scientific expertise and policy making}

\author{
Claire Marris, Pierre-Benoit Joly, Stéphanie Ronda and \\ Christophe Bonneuil
}

This paper examines the role of the precautionary principle (PP) in transforming the French regulatory landscape for genetically modified organisms used in food and agriculture over the last decade. Despite few explicit references to the PP, we argue that it has been instrumental. The changes do not result from a linear top-down process, as in the application of a new law. Instead, the PP has acted as a point of articulation for debates in different public arenas; through these debates, the PP has been progressively translated into pragmatic practices. New boundaries have been drawn between risk assessment and risk management practices. This has facilitated the progressive emergence of a distinct arena of scientific expertise and opens the possibility for the reciprocal emancipation of public decision and scientific expertise.

\footnotetext{
Claire Marris, Pierre-Benoit Joly and Stéphanie Ronda are at TSV Research Unit, INRA, Ivry, France 94205. Christophe Bonneuil is at Centre Alexandre Koyré, CNRS, Paris, and is a research associate at TSV Research Unit. E-mails: joly@ivry. inra.fr; marris@ivry.inra.fr; bonneuil@damesme.cnrs.fr.

Data for the period 2002-2005 was collected for the project 'Precautionary Expertise for GM Crops' (PEG), funded by the European Commission, Quality of Life programme, socioeconomic aspects (contract no QLG7-2001-00034). The authors are also grateful to the Food Directorate of the French Ministry of Agriculture, the CNRS and the European Commission for their earlier financial support.
}

0 INCE THE LATE 1990s, in France, as elsewhere, the use of the precautionary principle (PP) has become generalised, well beyond environmental policies. It renews the way science and decision making are articulated. It puts a strong emphasis on the limits of scientific knowledge and draws attention to uncertainty and ignorance. It also implies a new way to conceive decision processes as sequences of measures that may be temporary and reversible, and that have to be adapted to the state of information, proportionate to the importance of the potential damage and effective.

Thus, the PP gives good reasons to scrutinise the quality and robustness of scientific knowledge. As such, it potentially alters scientific expertise, and public debates about innovations and their risks. These broad principles are generally accepted, but the PP remains open to a diversity of interpretations when it comes to implementing it in practice. It has been argued that the PP should be considered as an 'approach' rather than a 'principle'. Some French jurists argue that it has the characteristics of a legal standard rather than a ready-made rule. In the former sense, the PP opens a space for negotiations that link the internal logic of law with external elements (policy, science, ethics, and so on) and therefore involves hybrid ways of constructing rules and norms (Lascoumes, 1997; Boy, 1999).

We start by identifying the different arenas where the PP has been discussed in order to describe how various 'hurdles' progressively contribute to the definition of the PP and the emergence of a new 
Claire Marris has a PhD in molecular biology and MSc in science policy; her research focuses on public perceptions of risks, public participation in science and technology policy, public controversies about innovations and their risks, and scientific expertise.

Pierre-Benoit Joly, economist and sociologist, is Directeur de Recherche at the National Institute of Agronomic Research (INRA) in France. He holds a degree in agronomy (1982), a PhD in economics (1987) and an 'Habilitation à diriger les recherches' (1995). Since January 2003, he has been the Director of the Research Unit TSV (Social Transformations related to Life Sciences and Life Forms). His research activities are focused on the forms of public participation in scientific activities and technology assessment (TA) (deliberate participatory TA but also public controversies) and on the current evolution of the interactions between science and public decision making.

Stéphanie Ronda is a student in political science. Her ongoing $\mathrm{PhD}$ analyses government policies for urban cultural development in Mexico and France, with a focus on how expert and lay knowledge is recognised and utilised.

Christophe Bonneuil is a senior researcher in the history of science (CNRS Paris and INRA-TSV). His main research interests are: the history and changing modes of production and regulation of knowledge in plant genetics from Mendel to $\mathrm{GM}$ crops and the comparative dynamics of risk research in GM crops in Europe and the USA.

conception of the links between science and policy. These hurdles are encounters between conflicting interpretations of the PP, which themselves represent different cognitive framings of the genetic modification (GM) controversy. As with many policy changes, the battle for a new cognitive frame is articulated with changes at the sub-legal level: institutions, organisations and practices (Surel, 2000). We then examine how such changes relate to new emerging frames created by policy actors through the PP.

\section{$P P$ in the dynamics of the GM controversy}

As in many other countries, the PP emerged in France as a result of new concerns related to environmental policy. It was first included in French law in 1995 with a wording very close to that of the 1992 Rio Declaration. Soon afterwards, as a result of several health crises, it was acknowledged that the PP had relevance beyond the environmental field. The HIV-contaminated blood scandal and the BSE (bovine spongiform encephalopathy or mad cow disease) crises were seen as paradigmatic of the absence of precaution (Hermitte, 1997; Hermitte and Dormont, 2000). The French controversy over genetically modified organisms (GMOs) emerged in this context and soon lay at the heart of the debate about the PP. The PP has thus been elaborated within the dynamics of the French GM controversy, for which we identify three periods.

\section{7-1999: PP enters political and legal arenas}

In February 1997, the French Government decided not to authorise the cultivation of a GM maize
(Bt176-derived varieties). This was the first occasion when a French Government took a decision that contradicted the advice from its scientific advisory committee, the Commission du Génie Biomoléculaire (CGB). The decision was so remarkable that the CGB Chair resigned in protest. The PP was invoked by the (right-wing) Government to justify this decision, but was also invoked a few months later by the subsequent (left-wing) Government to justify the opposite decision (to approve the cultivation of Bt176).

In both cases, reference to the PP was expected to confer legitimacy to governmental decisions in the face of growing opposition to GMOs by some nongovernmental organisations (NGOs) and farmers' organisations. However, the 'Bt176 saga' continued for several years and became the focus of a judicial debate about how to interpret the PP, as well as a spark for a wider controversy about GMOs (Joly et al, 2000; Noiville and Gouyon, 2000; Marris, 2000).

Bt176 was involved in two court cases of rather different kinds, both hinging on conflicting interpretations of the PP. The first was the trial in February 1998 of three activists from the left-wing farmers' trade union Confédération Paysanne who had broken into a Novartis warehouse. The defendants argued that they were implementing the PP, but the court decided that the PP could not be invoked to support actions against an activity - the storage of Bt176 seeds - that itself was strictly legal.

The second case followed a series of appeals lodged at the Conseil d'Etat (the administrative high court) by several NGOs against the authorisation for the cultivation of Bt176 varieties. These appeals argued that the authorisation was illegal because the risks had not been properly assessed, the correct administrative procedures had not been followed, and overall the PP had not been applied. Although the NGOs ultimately lost their case, an interim ruling issued in September 1998 apparently supported the way in which the NGOs had invoked the PP. This ruling stimulated an intense debate among lawyers and academics, including economists, sociologists, philosophers and biologists. The debate focused partly on what the PP implied for the practice of scientific expertise and public decision making on risk issues, and in particular on the following issues:

- How to define the level and nature of uncertainty that would warrant regulatory action. Various scales were proposed by different authors (Kourilsky and Viney, 2000; Chevassus, 2000; Godard, 2001), with different levels of uncertainty or plausibility being associated with different kinds of action, for instance, from greater research efforts to bans on an activity.

- How to take "societal considerations" into account in decision making. The citizen panel of the 1998 consensus conference had suggested the creation of a Biotechnology Commission, which would be composed of representatives of society. This idea 
was picked up and translated into a proposal for a "second circle of expertise" in a report of the Parliamentary Office for Technology Assessment (Le Déaut, 1998) and was later developed by the national consultative commission on food policy (CNA 2001).

- The need for a formal assessment of benefits that could be balanced with the risks. It was sometimes suggested that the "second circle of expertise" should carry out such an assessment, on the basis of expertise from social scientists and/or representatives from civil society.

In this context of an active intellectual debate and legal challenges to Government policy, Prime Minister Jospin asked two university professors (a lawyer and a molecular biologist) to prepare a report to clarify the meaning of the PP (Kourilsky and Viney, 2000). On the international scene, the Government was seeking to clarify its position for negotiations leading up to the World Trade Organisation (WTO) meeting to be held in Seattle in December 1999. Although this report had a broad scope, the GM controversy lay at the core. It sought to channel the PP into a scientistic rationale - to separate science from politics and to link policy more directly with scientific advice.

Meanwhile, the French Government also invoked the PP in negotiations about GMOs at the level of the European Union (EU). In November 1997, it cited the PP to justify a national moratorium on GM oilseed rape lines resistant to broad-spectrum herbicides, which had been authorised in the EU. And in June 1999, the PP was cited as the basis for the de facto moratorium declaration signed at the EU Council of Ministers, which was spearheaded by the French Government.

In this first period, a public controversy about GMOs and about the PP evolved, but it mobilised a relatively small number of specialised actors (NGOs, scientific experts, politicians, biotechnology companies), took place in a limited number of arenas (judicial courts, scientific expert committees, research institutes), and focused mostly on issues related to risks to human health or the environment. In the next phase, the debate intruded into more arenas and mobilised a wider range of actors who each sought to impose their own framing of the issue.

\section{0-2002: debate widens and shifts upstream}

After 1999, the framing of the GM debate shifted, under the influence of Confédération Paysanne, away from risk and towards broader political issues (Heller, 2002). Protagonists in the GM debate referred less often to the PP, and applied the concept to much wider issues than risk assessment and scientific expertise. The focus of the debate also moved upstream, from the commercial use of GM crops to field trials; and from regulatory approval of innovations to the orientation of research. In this context,

\section{Initially, a public controversy about GMOs and the PP evolved, but with limited actors, arenas and focus; then it expanded and a wider range of actors sought to impose their own framing of the issue}

the legitimacy of public-sector research institutes was challenged: whereas previously they had been assumed to act for the "public good", now their role, organisation, priorities and partnerships with industry were openly questioned.

As NGOs' mode of action evolved, an orchestrated campaign to destroy field trials began in 1999 . This brought the GM issue to the courts again when activists involved were arrested and charged. In 2001, the "CIRAD trial" was particularly high profile: it was widely covered by the media and led to the mobilisation not only of NGOs, but also of researchers seeking to defend the legitimacy of their activities.

In this trial, a public-sector research institute that specialises in research for agriculture in developing countries, CIRAD, was pitted against activists from the Confédération Paysanne. In court, both parties referred to the PP, with the prosecution arguing that the PP implied that the field trials were necessary, since more research was needed to reduce the uncertainty about risks, while the defence invoked the PP to call for a ban on the further development of GMOs until the uncertainty is resolved. Moreover, both sides relied on scientific experts as witnesses.

In its judgement, the court sidestepped this debate about the PP as a principle of action versus abstention. It emphasised instead that any application of the PP depends on the definition given to "proportional and effective measures". The judge did not accept the argument of the accused according to which their actions represented such precautionary measures.

As the intensity of field-trial destructions increased, the Government announced that it would organise a public debate on the issue. The "Débat des quatre sages" (Four Wise Men's debate) took place in February 2002. It provided a platform for most key protagonists to express themselves in public and resulted in a report written by the four organisers, who were Presidents of four consultative commissions dealing respectively with food policy, technology assessment, bioethics and sustainable development (Babusiaux et al, 2002).

Their recommendations provided novel dimensions to accounts of the PP. The report emphasised that field tests, in contrast with laboratory 
experiments, take place in a "social space", and that, as a result, it is legitimate for representatives of society to have their say about such activities, and it is reasonable to expect measures to be taken to protect surrounding persons and activities, in this case nonGM agriculture. They recommended that field experiments should be subject to measures to ensure: public information and consultation; the participation of local mayors in the decision; legal liability; and the protection of organic agriculture.

Moreover, the report suggested that the kind of risk assessments conducted were not sufficient, because proposals for field trials should be submitted to a wider appraisal, which should be based on a "principle of parsimony". This would assess whether release into the environment was necessary, or whether the same results could be obtained from experiments conducted in laboratories or greenhouses, and whether the potential interest of the trial justified intrusion into the social space.

The Four Wise Men's debate was an important moment in the public controversy on GMOs and contributed to a broadened interpretation of the PP. Because the Government changed shortly after its publication, its policy recommendations were never formally acknowledged, nor implemented. Nevertheless, the report continues to be cited by many different actors in different contexts and arenas, to lend support to their positions, both for and against field trials.

\section{3-2005: conflicting expertise and regional bans}

From 2003 to 2005, the controversy extended to many local scenes, with an increasing number of local and regional governments attempting to ban the cultivation of GMOs in their territories. These bans often invoked the PP. They were challenged in court by the central Government, which initially won on the basis that decisions about the cultivation of GM crops were under the responsibility of central authorities. At the same time, however, the idea that local mayors should be able to have a say about what happens in their locality gained more legitimacy in public spheres and in Government.

Another key development during this period was the increasing visibility of conflicting scientific expertise, which is discussed below. More generally, explicit references to the PP by actors of all kinds decreased after 2001. However, the academic debate on the PP was rekindled in 2003 by the proposal of President Chirac to introduce the PP into the French Constitution. The Academy of Sciences strongly opposed the move, while a network of NGOs, citizens and scientists mobilised to support the idea.

A new law for the regulation of GMOs was being prepared in mid-2005. This law had been repeatedly delayed by internal conflicts, in particular, between the Ministry for the Environment and the Ministry for Agriculture. The most contentious issues have been how much power to give mayors about the cultivation of GMOs in their communes, and whether and how to provide for input from civil society into decision-making. According to a preparatory parliamentary report, field experiments should respect three basic principles: precaution, parsimony, and transparency (Le Déaut and Ménard, 2005). This exemplifies how the PP has become associated with other principles that imply that actors other than scientists need to be involved in decision-making, and that risk assessments can no longer be framed in the narrow way that had been accepted until 1996.

\section{Evolutions in risk analysis}

We now turn to the analysis of transformations in the institutions, organisations and practices involved in risk assessment and risk management for GMOs in France.

\section{New institutional arrangements}

Until 1998, the CGB was the only expert body dealing with GM risk assessment, but by 1999, there were two more: AFSSA for food safety and a "Biovigilance Committee" for monitoring the long-term impacts of large-scale commercial cultivation of GM crops. The latter has not been very active, because there has been almost no commercial cultivation of GM crops in France, even though 12 varieties of GM maize were authorised in 1997-98.

However, the creation of the national Food Safety Agency (AFSSA) in 1999 has significantly transformed the regulatory landscape. AFSSA became responsible for the assessment of risks to human and animal health associated with GMOs and derived products that are destined to be used as animal feed or human food. The assessment was additional to that of the CGB, but did not replace it. From 1999 to 2004, proposals for EU-wide commercialisation of GM crops that included cultivation (submitted under Directive 90/220 then 2001/18) were assessed by both the CGB and AFSSA, whereas proposals (submitted under EC Novel Food Regulation 258/97) to import GM foods into the EU that did not include cultivation were assessed only by AFSSA.

In the wake of the BSE and HIV-contaminated blood scandals, AFSSA's establishment aimed to separate the institutions responsible for risk assessment, which would be based on best available scientific advice, from those responsible for risk management (decision-making), which could perhaps incorporate other dimensions, such as values and politics into their decision making. The agency would be responsible solely for risk assessment, and Government ministries for risk management.

In this context, a key theme in the creation of AFSSA was "independence". Much care was taken to establish rules and procedures to ensure that the scientific expertise produced was independent of Government, and was seen to be so. As a result, institutional arrangements for the agency and for its scientific 


\begin{tabular}{|c|c|c|}
\hline & CGB & AFSSA biotech expert committee \\
\hline $\begin{array}{l}\text { Institutional separation from decision } \\
\text { makers }\end{array}$ & No & Yes \\
\hline Independent budget & No & Yes \\
\hline Own website & No & Yes \\
\hline Members appointed by Government & Yes & Yes \\
\hline $\begin{array}{l}\text { Open call for scientific experts and } \\
\text { selection based on formal procedures }\end{array}$ & No & Yes \\
\hline $\begin{array}{l}\text { Systematic and rapid publication of } \\
\text { scientific opinions on web site }\end{array}$ & No & Yes \\
\hline $\begin{array}{l}\text { Minority opinions mentioned in published } \\
\text { opinions }\end{array}$ & No & Yes \\
\hline Public declaration of interest for experts & Yes & Yes \\
\hline Committee members financially remunerated & No & Yes \\
\hline Rules of procedure & $\begin{array}{l}\text { Established by the committee members, on } \\
\text { an ad hoc basis }\end{array}$ & $\begin{array}{l}\text { Common rules for all the expert committees of } \\
\text { AFSSA }\end{array}$ \\
\hline Membership by representatives of society & $\begin{array}{l}\text { Representatives of consumer NGOs, } \\
\text { environmental NGOs, industry, farming } \\
\text { organisations and trade unions appointed } \\
\text { as full members }\end{array}$ & $\begin{array}{l}\text { All members appointed for their scientific } \\
\text { competence (this includes one sociologist); } \\
\text { private-sector scientists excluded; no NGO } \\
\text { representatives }\end{array}$ \\
\hline
\end{tabular}

expert committees are far more codified and transparent than for the CGB (see Table 1). In particular, AFSSA established novel procedures for appointing experts to its scientific committees, including an open call and formal selection process; and ensured that all scientific opinions generated by the agency were posted on their website rapidly, and before any ensuing decision is made by the Government.

In contrast, the CGB has remained embedded within the Ministry of Agriculture. Members have continued to be nominated by the Government without any formal or transparent selection process. It does not have its own website: information about the CGB and its opinions are posted by the Ministry on a governmental website.

There have, however, been minor changes that attempt to clarify that the CGB's responsibility was limited to risk assessment. For example, the CGB modified the standard formula used in their opinions. Previously these had simply stated that the committee had a "favourable" or "unfavourable" opinion. Now they stated: "given the information provided and within the limits of current knowledge", the CGB considers that the proposed use of the GM plant "does not present any more risk for the environment or public health" than other commercialised varieties of the same plant species.

Moreover, the opinions became much longer and substantiated. Earlier opinions often consisted of only one page, stating the favourable/unfavourable opinion of the committee. More recent opinions are several pages long and go through the evidence in some detail.

These changes aimed to signal that the CGB provided only a scientific opinion about the potential risks associated with a release, not about the governmental decision that should follow. However, the same civil servants continued to act as both members of the CGB's secretariat and as representatives of the ministry responsible for related risk management decisions. This overlap meant that the separation between the risk assessment and risk management functions were not institutionalised, since these civil servants play an important role in setting the agenda and the limits of the remit for deliberations of the committee.

At the same time, the Government introduced new procedures that attempt to distinguish more clearly between the scientific advice on risk provided by the CGB and Government decisions. In 2003, decisions about whether to authorise an experimental field test began to be published on the government website, and formal decisions were even published when the government had "decided to suspend deciding". Moreover, since 2003, the standard formula used for these governmental decisions mentions that, in addition to the advice from the CGB, other considerations were taken into account, namely: consultation of the public, consultation of local mayors, and an inspection of the proposed local site.

The transparency of procedures for field-trial dossiers also increased. Information systematically posted on the governmental web site now included: the CGB opinions expressed; the governmental decisions taken; and the location of field tests authorised. Moreover, since 2003 the Government has organised a web-based public consultation procedure for these dossiers: members of the public are given two weeks to make comments after the CGB has issued its opinion and before the Government makes its 


\section{The overall trend has been towards greater autonomy for scientific expertise used for advising policy. It now has its own principles, its own procedures and its own institutions: the rules and procedures for scientific expertise are even codified in an official standard}

decision. The same level of transparency and consultation was not, however, implemented with respect to dossiers for commercial releases of GMOs: for example, the opinions issued by the CGB in 2003 were only made available to the public in February 2004, after pressure from some NGOs.

Despite such limitations, the overall trend has been towards greater autonomy for scientific expertise used for advising policy. It now has its own principles (competence, independence, transparency), its own procedures and its own institutions (Joly, 2005). The rules and procedures for scientific expertise are even codified in an official standard, and all members of scientific committees are required to declare that they have received a copy of this document.

\section{Link of scientific advice and governmental decisions}

Until 1996, the Government had systematically followed the advice of the CGB when deciding whether to authorise field tests conducted in France or to support EU-level proposals for the commercialisation of a GMO. The link appeared to be so direct that most protagonists, including those submitting proposals, talked about the CGB "authorising" (or not) a field trial.

Since 1997, the direct link between scientific expertise provided by expert bodies and governmental decision-making has been broken. The 1997 decision about GM maize Bt176 was the first case where the Government did not follow a CGB opinion. Successive Governments have, since then, on several occasions, taken decisions that were more restrictive than that implied by the risk assessment provided by French scientific expert bodies (for details see Marris et al, 2004); but the Chair and members of the CGB are not shocked by this situation - in stark contrast to the resignation of the Chair in 1997.

\section{Contradictory expertise}

The reforms of the regulatory system have led to an increased visibility for contradictory expertise. First, the existence of two separate expert bodies (the
CGB and AFSSA) examining the same GM products provides the opportunity for them to produce conflicting opinions. This has indeed occurred in many cases (for instance, for five out of the six products examined under Directive 2001/18 in 2003).

Secondly, composition of the CGB has been broadened. The previous composition had been criticised for being dominated by molecular biologists. When the Government re-appointed the members of the CGB in 1998, it sought to include people from a broader range of disciplines, and appointed one member with publicly known views against the use of GMOs, to promote what was described as "contradictory expertise" (Roy and Joly, 2000).

This composition has led to more virulent debates within the committee. Internal disagreements related to case-by-case evaluations are kept within the confidential confines of the committee, but some members published general statements revealing discord in the CGB's annual reports for 1999-2004. The depth of disagreements ended up being exposed in the press in April 2004, through the actions of an NGO specialising in counter-expertise for GMOs (CRIIGEN), which forced the Government to make public the minutes of the CGB meetings. These revealed the high level of adversarial debate within the committee, and that, on at least one occasion, the critical opinion of one member had been ignored when issuing a favourable opinion. By contrast, disagreements within the AFSSA committee appear as minority views in the published opinions; but, as for the CGB, the minutes are not routinely made public.

Media coverage of these conflicts between different experts and/or expert bodies has led to growing criticism. Many actors argue that contradictory expertise is a source of confusion that may erode the legitimacy of public decision-making. To avoid overlaps among the remits of several scientific committees, the 2005 Parliamentary Report on GMOs recommends the creation of a "vertical" committee that would conduct risk assessments at all stages of GMO use: contained use in laboratories and greenhouses; experimental releases into the environment; commercial releases; and post-market monitoring (Le Déaut and Ménard, 2005).

\section{Conclusion}

Regulatory changes for GMOs in France offer an interesting perspective on the way the PP may contribute to the transformation of public policy. The first use of the PP in the GM debate by French governments in 1997 and 1998 to justify GM policies went beyond measures related to a priori risk assessments: they referred also to measures related to labelling, biovigilance and public debate. The Government later sought to delimit the PP in a more narrow and scientistic way - more similar to the European Commission Communication on the PP (CEC, 2000). 
Nevertheless, wider interpretations gained ground as the PP was mobilised and taken up by other actors in diverse arenas. The PP maintained a high profile in the controversy about agricultural GMOs in France: it remained a key reference point for many actors, has been used in legal proceedings, and has now been introduced into the French constitution.

During this controversy, the definition of the PP remained relatively open, despite efforts to restrict its meaning. Yet, far from emptying it of any meaning, this openness enabled the PP to act as a space that linked previously unconnected debates about: the use of science in decision-making; societal input into decision-making; the orientation of publicsector research; and alternative food and agriculture systems.

Throughout these debates, different meanings were given to the PP by different actors, and it was used both to support and to oppose the development of GM crops and foods. In public meetings and court proceedings, the main points of divergence concerned whether the PP was a principle of action or inaction. On one hand, the PP was invoked by NGOs to request bans on the deliberate release of GMOs (even for experimental purposes) until proof of safety could be obtained. On the other hand, some scientists and biotechnology firms argued that field experiments or even large-scale commercial use was necessary to determine whether any serious risks were involved.

In addition, these debates focused on whether opponents' actions (the destruction of GM crops) was "proportionate" to the potential risks involved. In these public debates, there was no discussion about what the PP meant for the conduct of risk research, risk assessment or risk management. The PP was simply invoked in a rhetorical way to support or attack a particular regulatory decision.

These uses of the PP in the public controversy stimulated a debate among academics, who sought to propose more formalised definitions. In contrast to the debates in public meetings and legal courts, the debate among academics focused on practices related to risk analysis, and in particular on the separation between risk assessment and risk management, on the organisation of scientific expertise and on the role of non-scientists in the decision-making process. None of the definitions or approaches put forward by these academics was ever applied in a linear way and it would be easy to believe that these deliberations on the PP, and indeed the PP itself, has had no effect on the reforms of the risk-regulation system that have occurred in the last decade.

During our interviews with professionals involved in regulation (members of scientific expert committees and civil servants in relevant Government departments), the PP was hardly ever mentioned; and when queried about it, these interviewees generally stated that the PP was a "political" concept that had had no influence and was not an operational concept. Indeed, these actors hardly acknowledged that any major changes had even occurred in the regulatory system, let alone recognised that these changes might have occurred as a consequence of the public debate. They tended to claim that risk assessment had always been, and continued to be, performed according to "good scientific standards".

As we have seen, however, the regulatory landscape has been radically transformed, and many of the reforms can be described as more "precautionary", according to at least some definitions of the PP. We believe that the academic debate and the PP more generally have had a diffuse but significant influence on these reforms. The PP has been instrumental in several ways:

- As the rationale used by the Government to legitimise various moratoria (including the EUlevel de facto moratorium of 1999): given some lack of knowledge, it was argued that provisional bans had to be implemented while further research was conducted to resolve the uncertainty. This helped to stimulate the creation of a new field of GM biosafety research, which has become independent from the risk-regulation system (Marris et al, 2004; Bonneuil et al, submitted).

- For the promotion of more robust knowledge in scientific advice for policy, which encouraged reforms in the organisation of scientific expertise: the functional separation of risk assessment and risk management; changes and codification in the composition of scientific advisory committees, in their rules of procedure; and an increase in the transparency of the regulatory system.

In these ways, the PP has stimulated the progressive emergence of a new arena of scientific expertise, independent from public policy. This includes both scientific expertise used in policy advice (risk expertise) and the production of scientific knowledge used in risk assessment (risk research), which had both been embedded within the regulatory system until 1996. These changes in turn led to publicly visible instances of conflicting scientific expertise, which opened up a further space for debate and enhanced epistemic tensions. This opening fed the inflationary use of expertise that led to what Weingart (1999) calls an "expansion process": the controversy was pushed into a realm of uncertain knowledge, towards areas of disputed boundaries between un/reliable scientific information.

We then observe a contraction process that is exemplified by:

- Further debates about how best to provide a functional separation between risk assessment and risk management - an attempt at separating science from politics. For example, some actors accuse AFSSA of overstepping its remit by getting involved in risk management rather than limiting itself to risk assessment.

- Discussion about whether and how to create 
institutions and procedures to enable civil society to have an input into decision-making — an attempt at separating facts from values.

- Increasing calls for the concentration of all scientific advice into a single committee, to avoid the emergence of conflicting scientific opinions on the same product or issue. This is similar to moves to concentrate scientific advice into EU-level committees, to avoid or overcome conflicting scientific opinions emerging from EU member states.

These contraction dynamics could be interpreted as classic boundary work. In other words, based on a strong belief in the purity and objectivity of scientific knowledge, the actors are attempting to protect scientific institutions by shifting the boundaries between what counts as science and what counts as non-science (for instance, politics, ethics, social factors). Instead, however, we consider that the new boundaries drawn between practices (and the codification of links between them) facilitate the progressive emergence of a distinct arena of scientific expertise, characterised by a specific grammar (rules, institutions, symbolic referential and so on). This opens up the possibility for a reciprocal emancipation of public decision and scientific expertise.

\section{References}

Babusiaux, C, J-Y Le Déaut, D Sicard and J Testart (2002), "Rapport à la suite du débat sur les OGM et les essais au champ" (Ministère de l'Aménagement du Territoire de l'Environnement, Paris).

Boy, L (1999), "La nature juridique du principe de précaution", Natures Sciences Sociétés, 7(3), pages 5-11.

Bonneuil, C, P-B Joly and C Marris (submitted), "Democratizing experiment? The construction of GM-crop field trials as a social problem in France", Science Technology and Human Values.

CEC, Commission of the European Communities (2000), "Communication from the Commission on the Precautionary Principle", Brussels, COM (2000) 1.

Chevassus, B (2000), "L'analyse du risque alimentaire: quels principes, quels modèles, quelles organisations pour demain?", paper presented at the OECD conference Scientific and Health Aspects of GM Foods, Edinburgh, 28 February1 March.
CNA, Conseil National de l'Alimentation (2001), "La nécessité du débat public et ses aspects méthodologiques dans le domaine alimentaire" (Ministère de l'Agriculture, Conseil National de l'Alimentation, Paris).

Godard, O (2001), "Précaution légitime et proportionalité", Risques, 47, pages 95-100.

Heller, C (2002), "From scientific risk to paysan savoir-faire: peasant expertise in the French and global debate over GM crops", Science as Culture, 11, pages 5-37.

Hermitte, M-A (1997), "Le principe de précaution à la lumière du drame de la transfusion sanguine en France", in O Godard (editor), Le principe de précaution dans la conduite des affaires humaines (MSH et INRA, Paris) pages 179-198.

Hermitte, M-A, and D Dormont (2000), "Propositions pour le principe de précaution à la lumière de l'affaire de la vache folle", in Kourilsky and Viney (2000), pages 341-386.

Joly, P-B (2005), "La sociologie de l'expertise scientifique: les recherches françaises au milieu du gué: risques, crises et incertitudes: pour une analyse critique", Cahiers du GIS Risques Collectifs et Situations de Crise, 3, pages 117-174 (CNRS, Grenoble).

Joly, P-B, G Assouline, D Kréziak, J Lemarié and C Marris (2000), "L'innovation controversée: le débat public sur les OGM en France", Rapport à la DGAL, INRA, Grenoble, available at <http://www.inra.fr/Internet/Directions/SED/sciencegouvernance/>, last accessed 5 August 2005.

Kourilsky, P, and G Viney (2000), Le principe de précaution (Odile Jacob/La Documentation Française, Paris).

Lascoumes, P (1997), "La précaution, un nouveau standard de judgement", Esprit, Novembre, pages 129-140.

Le Déaut, J-Y (1998), "De la connaissance des gènes à leur utilisation - Première partie: L'utilisation des OGM dans l'agriculture et dans l'alimentation", Tome 1: Conclusions du Rapporteur (Office Parlementaire d'Evaluation des Choix Scientifiques et Technologiques, Paris)

Le Déaut, J-Y, and C Ménard (2005), "Rapport fait au nom de la mission d'information sur les enjeux des essais et de l'utilisation des Organismes Génétiquement Modifiés", Rapport no 2254, Assemblée Nationale, Paris).

Marris, C (2000), "Swings and roundabouts: French public policy on agricultural GMOs since 1996", Politeia, 60, pages 22-37.

Marris, C, S Ronda, C Bonneuil and P-B Joly (2004), "France: battling with expertise", national report for the project 'Precautionary Expertise for GM Crops', available at <http:// technology.open.ac.uk/cts/peg/index.htm>, last accessed 5 August 2005

Noiville, C, and P-H Gouyon (2000), "Principe de précaution et organismes génétiquement modifiés. Le cas du maïs transgénique", in Kourilsky and Viney (2000), annexe 2, pages 277-340.

Roy, A, and P-B Joly (2000), "France: broadening precautionary expertise?", Journal of Risk Research, 3(3), pages 247-254.

Surel, Y (2000), "The role of cognitive and normative frames in policy-making", Journal of European Public Policy, 7(4), pages 495-512.

Weingart, P (1999), "Scientific expertise and political accountability: paradoxes of science in politics", Science and Public Policy, 26(3), June, pages 151-161. 